KasSanis, B. (1956). J. gen. Microbiol. 15, 620-628

\title{
Serological Relationship between Potato Paracrinkle Virus, Potato Virus S and Carnation Latent Virus
}

\author{
By B. KASSANIS \\ Rothamsted Experimental Station, Harpenden, Hertfordshire
}

SUMMARY: Evidence is given that potato paracrinkle virus, potato virus $\mathbf{S}$ and carnation latent virus are serologically related and should be considered as related virus strains, although they differ considerably in their host range and pathogenicity, and only carnation latent virus is transmissible by aphids. It is suggested that the three have evolved from a common aphid-transmitted ancestor. In addition to the antigens which the three have in common, each has many specific ones, and the two strains from potato are more closely related to one another than to the carnation virus. No plant of the potato variety King Edward was found free from paracrinkle virus, and no Arran Victory plant free from virus $S$. Minor variants of both paracrinkle virus and of virus $S$ were detected; it is suggested that the variations in severity of symptoms developed when Arran Victory plants are grafted with King Edward scions reflect the various degrees to which different isolates interfere with each other's multiplication. Most isolates of virus $\mathbf{S}$ interfere only slightly with the multiplication of paracrinkle virus.

Salaman \& Le Pelley (1930) found that plants of the potato variety Arran Victory became diseased when grafted with scions from apparently normal plants of the variety King Edward. They gave the name paracrinkle to the disease in Arran Victory plants, and since their original observation every plant of the variety King Edward which has been tested has been found to contain paracrinkle virus. This virus has not been found to occur naturally in any other variety of potato or in any other plant, and it has featured frequently in speculations about the origin of viruses, usually with the suggestion that it might be an intrinsic component of the original King Edward seedling (Bawden, 1939; Darlington, 1944, 1949; van der Plank, 1948). For long it was thought to be transmissible only by grafting, but Bawden, Kassanis \& Nixon (1950) showed that it could be transmitted by mechanical inoculation of sap, particularly to tomato, and that infected plants contained characteristic elongated particles.

While studying viruses which occur in the carnation (Dianthus caryophyllus L.), I found one, which I called carnation latent virus, that had particles apparently identical with those found in tomato plants infected with paracrinkle virus. Plants infected with paracrinkle virus also reacted specifically with antisera prepared against carnation latent virus. It then seemed that paracrinkle and carnation latent virus might be serologically related, that is, were strains of one type virus. But this idea later appeared untenable because I found that apparently healthy plants of many other potato varieties also contained a virus which reacted specifically with antisera prepared against carnation latent virus. Not only were these other potato varieties free from 
paracrinkle virus, but many of them, such as Arran Victory, became diseased when infected with it. It seemed probable that these varieties contained potato virus S, which Ouboter (1951) and Rozendaal (1952) described as prevalent in apparently healthy plants of many Dutch potato varieties. That this was so was shown by tests with an antiserum against potato virus $\mathbf{S}$ kindly provided by Professor E. van Slogteren (Laboratory for Flowerbulb Research, Lisse, Holland). This antiserum also precipitated specifically with sap from King Edward plants and with sap from plants infected with carnation latent virus. Thus it was clear that carnation latent virus and potato virus $\mathbf{S}$ were serologically related to one another; but the results from tests with King Edward had two possible interpretations. One was that paracrinkle virus was serologically related to potato virus $S$ and carnation latent virus; the other that King Edward plants contain not only paracrinkle but also potato virus $\mathbf{S}$. Serologically related viruses are usually mutually antagonistic in plants, and plants systemically infected with one usually resist infection with another. As varieties like Arran Victory are infected with virus $\mathbf{S}$ and yet readily succumb to infection with paracrinkle virus, paracrinkle and $S$ viruses seemed unlikely to be related, and I suggested (Kassanis, 1955) that King Edward potatoes contained paracrinkle and virus $\mathbf{S}$ and that the elongated particles depicted by Bawden et al. (1950) were probably virus $S$ and not paracrinkle. The further work I have now done, and which is described below, has led me to revise this opinion and to conclude that apparently healthy plants of King Edward potato contain only one virus, that of paracrinkle, which, as also suggested by Wetter \& Brandes (1956), is related to potato virus $S$.

\section{METHODS}

Carnation latent virus was propagated in Sweet William plants (Dianthus barbatus L. var. Sutton's Scarlet). Tubers of King Edward and Arran Victory, free from all known viruses except potato paracrinkle and potato $S$, were kindly supplied by Dr G. Cockerham. Many tubers of these two varieties from different stocks were also tested in an unsuccessful attempt to find virus-free stocks. Seeds of Solanum demissum Lindl. (Commonwealth Potato Collection nos. 2167 and 2168) were kindly supplied by Dr W. R. S. Wortley and tubers of the Dutch variety Profijt by Dr Rozendaal.

To facilitate mechanical transmission 'Celite' was always added to the inoculum. Sap from Sweet William plants contains an inhibitor which prevents the mechanical transmission of carnation latent virus from carnation to other species of plants, therefore this virus was transmitted by the aphid Myzus persicae Sulz. A larger proportion of aphids transmitted when these were left without food for $2-4 \mathrm{hr}$. before feeding for a few minutes on the infected plants than when they fed for long periods on the infected plants. Infective aphids transmitted the virus only to the first test plant when a series of plants was colonized at hourly intervals. The virus is not readily transmitted by aphids and healthy plants were therefore colonized with 15-20 aphids/plant; with Sweet William these conditions usually infected $50 \%$ of the plants. Many 
attempts to transmit a virus by aphids from King Edward or Arran Victory potato plants, under a variety of conditions, all failed.

Paracrinkle virus was detected by grafting on to Arran Victory potato plants, and the other viruses were detected serologically. All tests for potato virus $\mathbf{S}$ in King Edward, or in other plants infected from it, were made with antiserum prepared against carnation latent virus, to avoid the possibility of confusing reaction with paracrinkle virus, should this be unrelated to potato virus $\mathbf{S}$.

Antisera to the viruses carried by King Edward and Arran Victory potato plants were produced by injecting rabbits with partially purified virus preparations, made either by sedimentation in the ultracentrifuge or by precipitation with ammonium sulphate. The rabbits were bled and the sera separated after six intravenous injections of $2.5 \mathrm{ml}$. of virus preparations, given at 3-day intervals. The antisera prepared against carnation latent virus antiserum did not precipitate with sap from healthy Sweet William plants, and the antisera against the potato viruses did not precipitate with sap from healthy potato plants, variety Majestic. The serological tests were made as previously described (Kassanis, 1955); unless otherwise mentioned the antisera were diluted to $1 / 40$. For brevity, the antisera prepared against the viruses present in the two potato varieties will be referred to as antiserum against King Edward and antiserum against Arran Victory.

For cross-absorption tests antisera and centrifuged sap from plants were mixed and left at room temperature for $24 \mathrm{hr}$. after which the mixtures were heated for $10 \mathrm{~min}$. at $60^{\circ}$ and centrifuged. This heating did not affect the titre of the unabsorbed antibodies but removed normal plant proteins.

\section{RESULTS}

\section{Host ranges and symptoms}

Sap from King Edward potato plants was inoculated to various types of plants; infection occurred in tomato (Lycopersicum esculentum L. var. Kondine Red), potato (Solanum tuberosum L. var. Majestic and Profijt; S. demissum), and sugar beet (Beta vulgaris L. var. Kleinwanzleben E.). Except in sugar beet, the infections became systemic. All inoculated plants were tested for their ability to precipitate with carnation latent virus antiserum and for their ability to cause paracrinkle when grafted to Arran Victory potatoes. The second test could not be done directly from sugar beet, but sap from the inoculated leaves was inoculated to tomato plants, scions from which were later grafted to potato plants. Every plant whose sap precipitated with the carnation latent virus antiserum also caused paracrinkle, and the transmissions provided no evidence that King Edward potatoes contain two viruses. If they do contain two viruses then the two have similar host ranges.

Of the plants infected by inoculating sap from King Edward, only sugar beet was also infected by carnation latent virus, and even in this host the two viruses behaved differently, for carnation latent virus invaded plants systemically. 
Tomato plants seem to be susceptible to some strains of potato virus $S$ (Köhler, 1955) but not to others (Rozendaal \& Brust, 1955). In my tests tomato plants were very readily infected when inoculated with sap from King Edward, but they remained uninfected with virus S from Arran Victory, even when grafted with scions from this plant.

Two types of Solanum demissum became infected when inoculated with sap from Arran Victory and King Edward; but whereas type 2167 showed no symptoms, type 2168 developed a blotchy mottle and crinkling when inoculated from King Edward and a general chlorosis from Arran Victory. The symptoms were not considered reliable for the diagnosis of potato virus $S$, because uninoculated plants of type $\mathbf{2 1 6 8}$ also showed somewhat similar symptoms, although serological tests confirmed that they were free from potato virus $S$.

The potato variety Profijt is used in Holland as an indicator plant to test for potato virus $S$. I found it a very useful plant in demonstrating that paracrinkle virus and potato virus $S$ can multiply in the same plant, apparently without interfering with each other. Profijt plants inoculated separately with sap from King Edward or Arran Victory, or with a mixture of the two, showed no symptoms in the first year. In the next two years, the progenies from the plants inoculated with sap from Arran Victory again remained apparently healthy, but those infected from King Edward, or with the mixed inoculum, developed a mild but definite mottle. Serological tests with the three antisera gave identical results in both years. The plants infected from King Edward did not react with Arran Victory antiserum at a dilution 1/20, but did so with the antisera to King Edward and carnation latent virus. As the plants which were infected with mixed inoculum developed symptoms, reacted with the Arran Victory antiserum and produced paracrinkle when grafted to Arran Victory potato plants, it can be concluded that they were infected with paracrinkle and potato $\mathrm{S}$ from Arran Victory.

The severity of the blotchy mottle and crinkling of the leaves shown by Arran Victory plants infected with paracrinkle virus varies considerably in different plants. This was first stressed by Salaman \& Le Pelley (1930) and again by Bawden et al. (1950). Variations have been observed even when Arran Victory plants have been grafted with scions taken from the same King Edward plant. It cannot be attributed to growing conditions or age of the infected plants, because the progenies of one Arran Victory plant which showed mild symptoms were followed through three growing seasons and the symptoms remained unchanged.

\section{Properties in vitro}

If King Edward contained paracrinkle virus and virus S, it seemed unlikely the two would both have the same resistance to heating and the same dilution end-point. Attempts to separate the two, however, all failed. The temperature at which potato virus $S$ has been reported to be inactivated in vitro varies, depending possibly on the strain but more likely on the method used for testing. Köhler (1955) gave a value of $68^{\circ}-71^{\circ}$, Rozendaal \& Brust (1955) $50^{\circ}-60^{\circ}$, Wetter \& Brandes (1956) $60^{\circ}-65^{\circ}$, and Levieil (1954) less than $45^{\circ}$. In 
my tests $5 \mathrm{ml}$. samples of sap from King Edward plants were heated for $10 \mathrm{~min}$. at different temperatures and inoculated to tomato plants. A month later these were tested serologically with the carnation latent virus antiserum and also grafted to Arran Victory. The two tests gave identical results. In three experiments of this kind, using a total of 12 tomato plants per treatment, the inactivation end-point was between $80^{\circ}$ and $85^{\circ}$. This is $20^{\circ}$ higher than the thermal inactivation point found for carnation latent virus (Kassanis, 1955), with which tests were made in sap from Sweet William plants. It is also $20^{\circ}$ higher than that reported by Bawden et al. (1950), who examined heated sap from tomato plants infected with potato paracrinkle virus by means of the electron microscope and did not detect particles in sap heated for $10 \mathrm{~min}$. between 55 and $60^{\circ}$. I obtained yet another value when sap from King Edward was heated at different temperatures and then tested serologically. Unheated sap and sap heated at $45^{\circ}, 50^{\circ}, 55^{\circ}, 60^{\circ}$ or $65^{\circ}$ for 10 min. gave precipitation end-points the reciprocals of which were $32,8,4,2,1$ and 0 , respectively. Hence the method of testing seems important; insensitive methods record a much lower thermal inactivation point than methods such as inoculation to tomato, which presumably detects small quantities of virus. The serological test suggests that much of the virus is lost at temperatures far below the temperature required to inactivate all particles. The virus also rapidly inactivates when sap is kept at $20^{\circ}$, the serological activity disappearing in $24 \mathrm{hr}$.; at $35^{\circ}$ the precipitation end-point fell from $1 / 32$ to $1 / 2 \mathrm{in} 4 \mathrm{hr}$.

When tomato plants were inoculated with King Edward sap at various dilutions, there was again complete agreement between tests made serologically for potato virus $\mathrm{S}$ or by grafting to Arran Victory for paracrinkle. The number of tomato plants infected out of 4 were $4,4,3$ and 0 , respectively, with undiluted sap and dilutions of $1 / 10,1 / 100$ and $1 / 1000$. When, instead of tomato, the potato variety Majestic was inoculated there were 4, 4 and 0 infections out of 4 with undiluted sap and dilutions $1 / 10$ and 1/100. The prevalence of potato virus $S$ in different European and American potato varieties suggests that some strains of this virus other than that present in King Edward might be more infectious. When sap from Arran Victory was tested on plants of the variety Majestic it infected the plants at dilution $1 / 10$ but not at 1/100. Köhler (1955) gave the dilution end-point for potato $S$ as between $1 / 1000$ and 1/10,000. As with thermal inactivation, there is no agreement in the results obtained with different strains of potato virus $\mathbf{S}$.

\section{Serological tests}

After sap from any of the three plants (King Edward, Arran Victory and Sweet William infected with carnation latent virus) was mixed with antiserum prepared against any of the other two, no antigen remained that could be precipitated with the homologous antiserum. Therefore, if paracrinkle virus produces antibodies and precipitates with them, it must be serologically related to potato virus $S$ and carnation latent virus. If serological relationship be taken as a criterion that certain viruses are strains of the same virus, then potato virus $S$, carnation latent virus and paracrinkle virus should be strains 
of the same virus. The possibility remains, however, that paracrinkle virus did not produce antibodies or precipitate with them. If this were so, King Edward might contain a virus related to potato virus $S$ and carnation latent virus, and also to paracrinkle virus which was entirely unrelated to them.

That potato paracrinkle virus is unrelated to potato virus $\mathbf{S}$ seems unlikely, for it is easy to show that potato paracrinkle virus is precipitated by the antiserum to carnation latent virus. In one test $2.5 \mathrm{ml}$. of King Edward sap was mixed with $0.5 \mathrm{ml}$. carnation latent virus antiserum; after $2 \mathrm{hr}$. the precipitate was centrifuged down and resuspended in $2.5 \mathrm{ml}$. water. The suspension was inoculated, undiluted and at dilution 1/10, to 5 tomato plants each. Tests made later on the inoculated plants showed not only that they contained an antigen related to carnation latent virus antiserum, but that they also caused paracrinkle when grafted to Arran Victory potato plants.

Although all my results suggest that paracrinkle, potato $S$ and carnation latent virus are serologically related, they also show that these three viruses are far from being antigenically identical. Table 1 shows that the precipitation end-points of the antisera to carnation latent virus and to King Edward were

Table 1. Precipitation titres of the antisera to carnation latent virus and King Edward titrated against homologous and heterologous antigens

$\begin{array}{cc}\text { Infected Sweet } & \text { King } \\ \text { William sap } & \text { Edward sap } \\ \text { (dilution 1/10) } & \text { (dilution 1/4) }\end{array}$

Autisera to

Titre of antisera

Carnation latent virus King Edward

$\overbrace{\substack{1 / 1280 \\ 1 / 10}}^{\begin{array}{c}1 / 80 \\ 1 / 320\end{array}}$

much higher when titrated against sap containing homologous viruses than when tested against the heterologous viruses at the same concentrations. These, and similar results obtainęd when the antisera to carnation latent virus and Arran Victory were compared, suggest that the three viruses have only some antigenic groups in common. This is better shown in Table 2, which gives the results of tests on which antisera were absorbed with the heterologous antigens. The results suggest that carnation latent virus and the virus in King Edward probably have much less than half of their antigenic groups in common. The viruses from King Edward and Arran Victory are more similar and probably have about half of their antigenic groups in common.

King Edward antiserum when titrated against sap from Arran Victory always reacted at dilutions up to $1 / 40$, but Arran Victory antiserum did not always react at these dilutions when titrated against sap from King Edward. In one typical test sap from 5 plants of the variety King Edward of the same age and appearance, but raised from tubers collected from different parts of the country, were titrated against Arran Victory antiserum at $1 / 20$. The respective precipitation titres were: $0,1 / 2,1 / 16,1 / 16,1 / 20 ;$ but all plants reacted at $1 / 32$ with the antiserum to King Edward. The plant which did not react with Arran Victory antiserum at $1 / 20$ did react when the antiserum was used at $1 / 4$. 
The results indicate that the different King Edward plants contained virus strains with different degrees of relationship to the strain of virus $S$ used to produce the Arran Victory antiserum. That the strains of virus in different stocks of King Edward differ was also shown by cross-absorption tests. When the King Edward antiserum was absorbed with sap from a line of King Edward different from that used in preparing the antiserum, the absorbed serum still precipitated strongly with sap from the homologous line of King Edward, though it no longer precipitated with the line used for the absorption.

Table 2. Precipitation titres of absorbed and unabsorbed antisera to King Edward and carnation latent virus titrated against homologous and heterologous viruses

\begin{tabular}{|c|c|c|c|c|}
\hline Antisera to & & $\begin{array}{l}\text { Infected Sweet } \\
\text { William sap } \\
\text { (dilution } 1 / 10 \text { ) }\end{array}$ & $\begin{array}{c}\text { King } \\
\text { Edward sap } \\
\text { (dilution 1/4) }\end{array}$ & $\begin{array}{c}\text { Arran } \\
\text { Victory sap } \\
\text { (dilution } 1 / 4 \text { ) }\end{array}$ \\
\hline \multirow[t]{2}{*}{ King Edward } & $\begin{array}{l}\text { Absorbed with Sweet } \\
\text { William sap* }\end{array}$ & $0(1 / 2) \dagger$ & $1 / 320$ & - \\
\hline & Unabsorbed & $1 / 8$ & $1 / 320$ & - \\
\hline King Edward & $\begin{array}{l}\text { Absorbed with Arran } \\
\text { Victory sap } \ddagger \\
\text { Unabsorbed }\end{array}$ & - & $\begin{array}{l}1 / 320 \\
1 / 640\end{array}$ & $\begin{array}{l}0(1 / 20) \\
1 / 320\end{array}$ \\
\hline $\begin{array}{l}\text { Carnation } \\
\text { latent virus }\end{array}$ & $\begin{array}{l}\text { Absorbed with King } \\
\text { Edward sap } \$ \\
\text { Unabsorbed }\end{array}$ & $\begin{array}{l}1 / 1280 \\
1 / 1280\end{array}$ & $\begin{array}{l}0(1 / 20) \\
1 / 80\end{array}$ & - \\
\hline $\begin{array}{l}\text { * } 2 \mathrm{ml} \text {. antis } \\
\text { irus. } \\
+ \text { Figures in } \\
\ddagger 0.3 \mathrm{ml} \text {. ant } \\
\$ 0.5 \mathrm{ml} \text {. ant }\end{array}$ & $\begin{array}{l}\mathrm{m}+2 \mathrm{ml} \text {. of sap fron } \\
\text { ackets show the dilu } \\
\mathrm{ra}+5.7 \mathrm{ml} \text {. of sap fr } \\
\mathrm{ra}+9.5 \mathrm{ml} \text {. of a pre }\end{array}$ & $\begin{array}{l}\text { Sweet William } \\
\text { ion at which th } \\
\text { Arran Victo }\end{array}$ & $\begin{array}{l}\text { ts infected } v \\
\text { ration was } s \\
\text { lants. } \\
\text { m sap of } K\end{array}$ & $\begin{array}{l}\text { d. } \\
\text { d. }\end{array}$ \\
\hline
\end{tabular}

\section{DISCUSSION}

As it is impossible to prove a negative, so it is impossible to be sure that King Edward plants do not contain both paracrinkle virus and a virus which is related to potato virus $S$ and carnation latent virus. However, all my attempts to demonstrate a dual infection have failed, and until some evidence is found for this, it seems reasonable to assume that paracrinkle virus is serologically related to the much more widely distributed potato virus $S$ and carnation latent virus. This conclusion raises problems of nomenclature, for paracrinkle virus was the first to be discovered and named, and so the others should perhaps be regarded as strains of it and renamed appropriately.

There is nothing unusual in serologically related strains of a virus differing in their host ranges, pathogenicity and method of transmission to the extent that paracrinkle, $\mathrm{S}$ and carnation latent viruses differ from one another. Indeed, the only reason for doubting that paracrinkle virus and virus $S$ are not related strains is that plants infected with virus $S$ are still susceptible to infection by paracrinkle virus, for serologically related viruses are usually mutually antagonistic and plants systemically infected with one usually resist invasion by another. However, here again this behaviour is not unprecedented; Bawden 
\& Kassanis (1951) found two strains of potato virus $\mathrm{Y}$ which did not interfere with one another when multiplying in the same plant. Also, Matthews (1949) found with potato virus $\mathbf{X}$ that the extent to which infection with one strain protected plants against infection by another depended on the degree of serological relationship between them. My results suggest that paracrinkle virus and potato virus $S$ each has many specific antigenic groups, and, by analogy with the results with potato virus $X$, it is therefore not unexpected that they should fail to protect plants against one another. Perhaps they do interfere somewhat with one another and the extent to which they do this reflects the degree of their structural similarity. Different isolates of paracrinkle virus and different isolates of potato virus $S$ seem to differ from one another and, z.S already stated, the symptoms of paracrinkle produced in Arran Victory plarits by transmission even from the same King Edward plant can vary considerably. Salaman (1932) interpreted this variation as evidence that paracrinkle is caused by the combined action of two viruses which occasionally dissociate and then produce less severe symptoms. There is, though, no evidence for such a dual infection, and certainly not for the presence of potato virus $Y$, as postulated by Salaman; a much more likely explanation is that the severity of symptoms reflects the extent to which the particular form of virus $S$ already present in the Arran Victory plant interferes with the establishment of the form of paracrinkle virus present in the infecting King Edward plant.

The conclusion that paracrinkle virus, virus $S$ and carnation latent virus are related to one another provides an explanation for the universal occurrence of paracrinkle virus in King Edward potatoes without need to postulate that it was a product of the original seedling. It seems likely that all three viruses have originated from a common ancestor which was aphid-transmitted, but that only one line of descendants, represented by carnation latent virus, now retains this character. There are many recent examples of viruses acquiring or losing a character as a result of invading a new host, or after a prolonged sojourn in a new host, and these include examples of losing or acquiring the ability to be transmitted by a given insect (Black, 1953; Hollings, 1955; Watson, 1956). And in a vegetatively propagated plant like the potato, loss of insect-transmissibility would not lead to the disappearance of the virus as it might in annual plants coming from seed, for the virus is perpetuated through the tubers. To survive for long this way in commercial potato varieties, however, a virus must not cause bbvious symptoms. Hence, if paracrinkle virus ever existed in other varieties, it has been eliminated because of the disease it caused in them, but in King Edward there has been no selection against it.

I am indebted to Miss Sally Eisler for technical assistance.

\section{REFERENCES}

Bawden, F. C. (1939). Plant Viruses and Virus Diseases, 1st. edition. Leiden, Holland: Chronica Botanica Co.

Bawden, F. C. \& Kassanis, B. (1951). Serologically related strains of potato virus $\mathrm{Y}$ that are not mutually antagonistic in plants. Ann. appl. Biol. 38, 402. 
Bawden, F. C., Kassanis, B. \& Nixon, H. L. (1950). The mechanical transmission and some properties of potato paracrinkle virus. J. gen. Microbiol. 4, 210 .

BLACK, L. M. (1953). Loss of vector transmissibility by viruses normally insect transmitted. Phytopathology, 43, 466 (abstract).

Darlington, C. D. (1944). Heredity, development and infection. Nature, Lond. 154, 164.

Darlington, C. D. (1949). Les plasmogènes. Colloq. int. Cent. nat. Rech. sci. 8, 123.

Hollings, M. (1955). Investigation of Chrysanthemum viruses. 1. Aspermy flower distortion. Ann. Appl. Biol. 43, 86.

Kassanis, B. (1955). Some properties of 4 viruses isolated from carnation plants. Ann. appl. Biol. 43, 103.

Köhler, E. (1955). An unknown potato virus. NachrBl. dtsch. PflSchDienst, Stuttgart, 7, 22.

LevieIl, P. (1954). Étude des virus S. Rev. Aval Douai Breiz, no. 27, 9.

Matthews, R. E. F. (1949). Studies on potato virus X. II. Criteria of relationships between strains. Ann. appl. Biol. 36, 460 .

Ouboter, De Bruyn, M. P. (1951). A new potato virus. Proc. Conf. Potato Virus Diseases, Wageningen-Lisse, 1951, p. 83.

Plank, J. E. van Der (1948). Origin of some plant viruses. Nature, Lond. 162, 291.

Rozendaal, A. (1952). New virus problems in the potato. Meded. ned. alg. Keurinsd. LandbZad. 8, 94.

Rozendaal, A. \& Brust, J. H. (1955). The significance of potato virus $\mathrm{S}$ in seed potato culture. Proc. 2nd Conf. Potato Virus Diseases, Lisse-Wageningen, 1954, p. 120.

Salaman, R. N. (1932). The analysis and synthesis of some diseases of the mosaic type. The problem of carriers and auto-infection in the potato. Proc. Roy. Soc. B, 110, 186.

Salaman, R. N. \& Le Pelley, R. H. (1930). Paracrinkle: a potato disease of the virus group. Proc. Roy. Soc. B, 106, 140.

Watson, M. A. (1956). The effect of different host plants of potato virus $\mathrm{C}$ in determining its transmission by aphids. Ann. appl. Biol. (in the Press).

Wetter, C. \& Brandes, J. (1956). Investigations on potato virus S. Phytopath. Z. 26, 81 . 